\title{
Planar (Rolling) Shear Strength of Structural Panels Using 5-point Bending Test ${ }^{1}$ (A⿱⺈⿻⺕口
}

\author{
Sei Chang $\mathrm{Oh} \mathbb{1}^{2, \dagger}$
}

\begin{abstract}
This study was conducted to evaluate the planar (rolling) shear strength of OSB (oriented strand board) panels and domestic plywood through 5 point bending test method in ASTM D2718 standard. The test specimens were prepared in parallel and perpendicular direction to major axis (along the length of panels) and tested up to failure, and failure modes were also examined. From the test results, rolling shear strength were found to be $1.32 \sim 1.94 \mathrm{~N} / \mathrm{mm}^{2}$ in parallel to major axis, and $1.46 \sim 1.99 \mathrm{~N} / \mathrm{mm}^{2}$ in perpendicular to major axis respectively. Little difference was found between parallel and perpendicular direction of rolling shear strength. There were no statistically significant differences in rolling shear strength between Canadian OSB and domestic plywood in the parallel direction, and between Chilean OSB and domestic plywood in the perpendicular direction. The shear failure was observed in all tested OSB panels, whereas shear failure, glue line delamination, and bending combined with shear failure were observed in the domestic plywood.
\end{abstract}

Keywords: planar (rolling) shear strength, oriented strand board, plywood, 5 point bending test, shear failure

\section{INTRODUCTION}

Currently, the domestic wood construction market is growing with an average of 15,000 houses built per year, and according to construction permit/construction statistics by Ministry of Land, Infrastructure, and Transport as of 2017, the number of wood construction and that of brick houses were 13938 and 7494, respectively, indicating the number of construction permits/constructions of wood construction is twice that of brick houses (MOLIT - Statistics of housing construction-Housing construction records. 2017).
The main materials used for wood construction are engineered wood such as dimension lumber and structural panel, whose performance needs to be certified to be used for wooden structures.

Among engineered wood, oriented strand boards (OSB) and structural plywood are mainly used for structural panels. These materials are mainly used as covering material for roof, floor and wall structures with reasonable price and suitable structural performance. OSB is a laminated composite material, which is regarded as an orthotropic material like wood, so it has facing with interlaminar shear and shear through

\footnotetext{
1 Date Received May 16, 2018, Date Accepted July 9, 2018

2 Department of Forest Resources, Daegu University, 201, Daegudae-ro, Gyeongsan-si, Gyeongsangbuk-do 38453, Republic of Korea

† Corresponding author: Sei Chang Oh (e-mail: osc@daegu.ac.kr, ORCID: 0000-0001-6747-5527)
} 
the thickness in use. performance. The interlaminar shear is also referred to as rolling shear or planar shear since shear is caused by external forces applied along the plane of the panel (Shrestha, 1999).

Due to the structural characteristics of wood construction, these sheathing cover materials are placed on the joists and serve as the vertical load resistance component and as the horizontal load resistance component through the horizontal diaphragm structure. For the wall structures, they are used as the main members of the horizontal load resistance elements, so they should maintain proper structural performance.

The shear performance of the OSB was measured mainly by the shear test on between the OSB and the nail(Hwang and Park, 2008; Oh, 2013), rather than on the shear performance of the structural panel itself and to measure the shear stiffness of a LVL through a tensile test (Oh, 2013).

The shear performance test of such a structural panel itself is often omitted during quality control process, due to the difficulty of the shear performance test method itself and the cost required for the test (Fridley and French, 2000). However, as the use of OSB becomes more common in wood construction, the shear performance is becoming a major factor in structural performance due to lateral loads such as wind and earthquake, and needs to be considered (Nadir and Jerrold, 2007).

The direct shear performance test method for structural panels is ASTM D2718. In this test method, the 5-point bending load test method is widely used since it is simple and economical, and the shear performance can be directly measured through it (Thomas, 2004; Nadir and Jerrold, 2007). Sretenovic et al. (2005) conducted a comparative study on the rolling shear performance of plywood and OSB using the 5-point bending test and the EN 789 test, and the 5-point bending test method was applied to the structural composites such as laminated veneer lumber (LVL) and parallel strand lumber (PSL) as well as structural panels (Bradtmueller et al., 1998; Frank and Bruce, 2000; Fridley and French, 2000).

In particular, the 5-point bending test for composite materials is considered a very efficient method for measuring the interlaminar shear force of a oriented composite material, because the effect of shear stress on the entire specimen is very large and the bending stress is close to zero (Kim and Dharan, 1995).

In this study, the 5-point bending test was applied to the OSB and domestic plywood which are widely used in the wood construction site, and the rolling shear force was measured to conduct a comparative study on their performance.

\section{MATERIALS and METHODS}

\subsection{Test material}

The structural panels used in this study were four kinds, 1 domestic plywood and 3 imported OSBs, imported from Europe, Canada and Chile, respectively, and purchased from professional companies to be used as test materials. Table 1 shows the thickness, density and moisture content of specimens from each structural panel of $4 \times 8$ size.

The test specimens parallel to the longitudinal direction from each structural panel had the dimensions of thickness $\times$ width $\times$ length $=11$ (plywood: 12$) \times$ $120 \times 400 \mathrm{~mm}$, while the test specimens perpendicular to the longitudinal direction had thickness $\times$ width $\times$ length $=11 \times 120 \times 290 \mathrm{~mm}$ (plywood: 12 ). Five test specimens were cut and randomly selected from each panel, a total of 15 test specimens were prepared in each type of panel. The specimens were conditioned at $20^{\circ} \mathrm{C}, 65 \%$ relative humidity for about 10 days before testing. 
Planar (Rolling) Shear Strength of Structural Panels Using 5-point Bending Test

Table 1. Basic properties of structural panels used in this study

\begin{tabular}{|c|c|c|c|c|c|c|}
\hline Type & Product origin & $\begin{array}{c}\text { Number of } \\
\text { panels }\end{array}$ & Grade & $\begin{array}{c}\text { Nominal } \\
\text { thickness } \\
(\mathrm{mm})\end{array}$ & $\begin{array}{l}\text { Density } \\
\left(\mathrm{g} / \mathrm{cm}^{3}\right)\end{array}$ & M.C. $(\%)^{1)}$ \\
\hline OSB & Canada & 3 & $\begin{array}{c}\text { APA } 24 / 16 \\
\text { (1R24/2F16/W24) }\end{array}$ & 11 & 0.63 & 5.9 \\
\hline OSB & Chile & 3 & $\begin{array}{c}\text { APA } 24 / 16 \\
\text { (1R24/2F16/W24) }\end{array}$ & 11 & 0.72 & 5.2 \\
\hline OsB & Europe & 3 & S-LB-MR ${ }^{2)}$ & 11 & 0.60 & 6.8 \\
\hline Plywood & Domestic & 3 & $\begin{array}{c}\text { Semi-water resistance, } \\
\text { 5-ply }\end{array}$ & 12 & 0.50 & 9.5 \\
\hline
\end{tabular}

1) ; measured with resistance type moisture meter after conditioning

2) ; surface-load bearing-moisture resistance grade

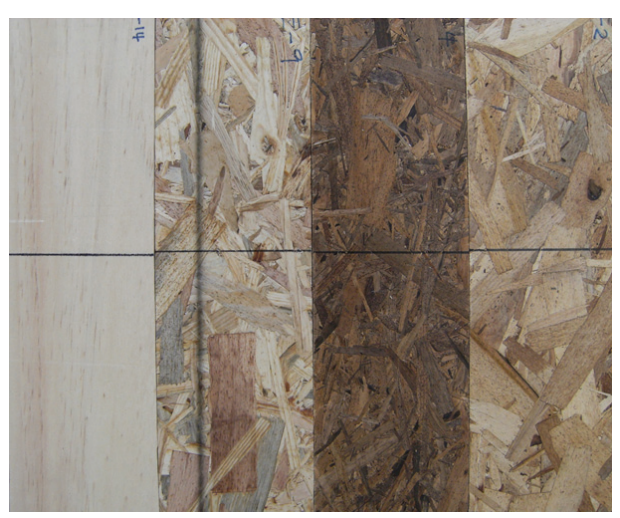

(a)
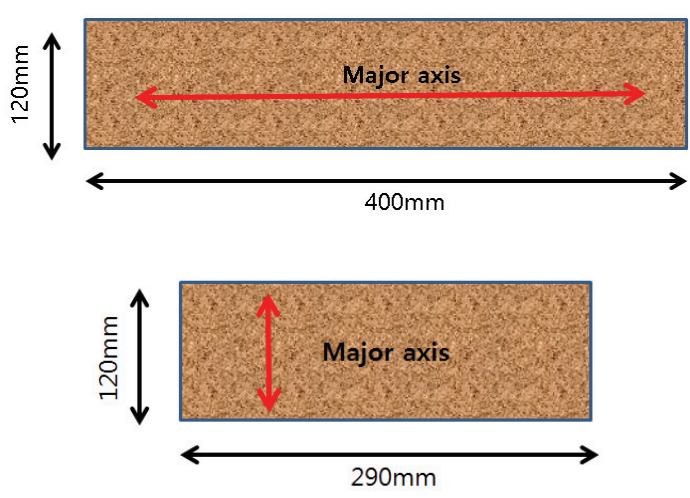

(b)

(a) From left to right : Plywood, OSB(Europe), OSB(Chile), OSB(Canada)

(b) Upper; parallel to major axis, down; perpendicular to major axis

Fig. 1. Configuration of test specimens for five point bending test.

\subsection{Test methods}

For each prepared test specimen, in accordance with ASTM D 2718 method, the maximum load was measured at the time of failure using a universal testing machine (DTU 900-H) as shown in Fig. 2.

The span $(\mathrm{L})$ of the test specimen parallel to the longitudinal direction of the panel in accordance with ASTM was $180 \mathrm{~mm}$, which corresponds to 16 times the thickness of the minimum span, and the specimen perpendicular to the longitudinal direction was 11 times the thickness of the minimum span, $120 \mathrm{~mm}$, respectively.

The load velocity at the test was $1.3 \mathrm{~mm} / \mathrm{min}$ and the rolling shear strength (fv) of the structural panel was calculated according to the following formula using the measured maximum load. 


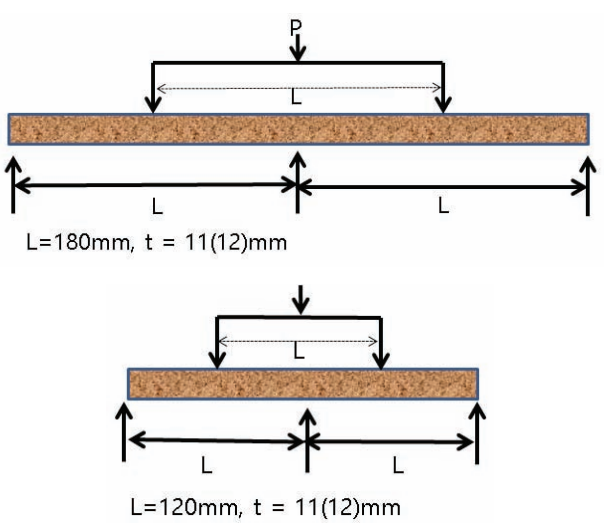

(a)

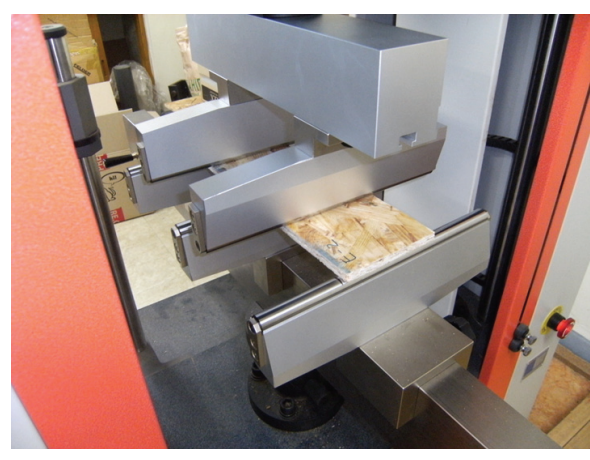

(b)

(a) upper: parallel to major axis, down: perpendicular to major axis

(b) Test configuration

Fig. 2. Five point bending test configuration and test set up according to ASTM D 2718.

$$
f_{v}=\frac{33 P}{64 b d}
$$

$P=$ Maximum Load $(\mathrm{N}), b=$ The width of specimen $(\mathrm{mm})$, $d=$ The thickness of specimen $(\mathrm{mm})$

ANOVA test and Duncan's multiple test for data analysis were performed using SPSS statistical program to verify the statistical difference for each measured value.

\section{RESULTS and DISCUSSION}

\subsection{Rolling shear performance of structural panels}

The typical load-deflection curves for the 5-point bending tests are shown in Fig. 3. As shown in the figure, the plywood showed a tendency to continuously resist shear even after the primary failure, except for the case of delaminatiomof the adhesive layer. In the case of OSB, all of them showed rapid drop after reaching the maximum load due to failure by rolling shear.
Table 2 shows the rolling shear strength and maximum bending stress parallel to the longitudinal direction for each structural panel. As shown in Table 2, C/OSB, plywood, N/OSB, and E/OSB are the order of rolling shear strength when parallel with the longitudinal direction, and the maximum rolling shear strength for C/OSB is $1.90 \mathrm{~N} / \mathrm{mm}^{2}$, the greatest of all.

Bradtmuller et al. (1997) reported that the mean rolling shear strength of OSBs with different widths and spans of specimens in the 5-point bending test was $0.81 \mathrm{~N} / \mathrm{mm}^{2}$, while Shrestha (1998) and French (2000) reported $1.13 \mathrm{~N} / \mathrm{mm}^{2}$, respectively, which shows that except for European OSBs, all values were high. This is thought to be due to the size and span conditions, such as the thickness and width of the specimen, and the directions.

Rolling shear strength perpendicular to the longitudinal direction was in the order of plywood, C/OSB, N/OSB and E/OSB, with plywood showing the greatest rolling shear strength of $2.38 \mathrm{~N} / \mathrm{mm}^{2}$.

This tendency is different from the case of the rolling shear strength parallel to the longitudinal direction. Sretenovic et al. (2004) pointed out that the structure 


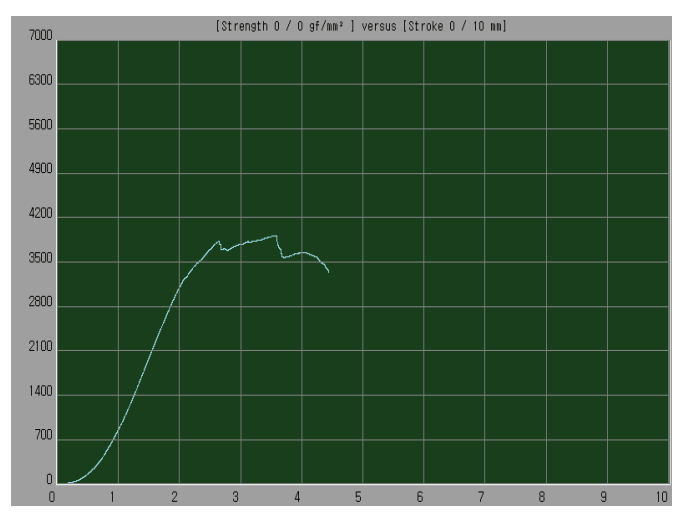

Plywood

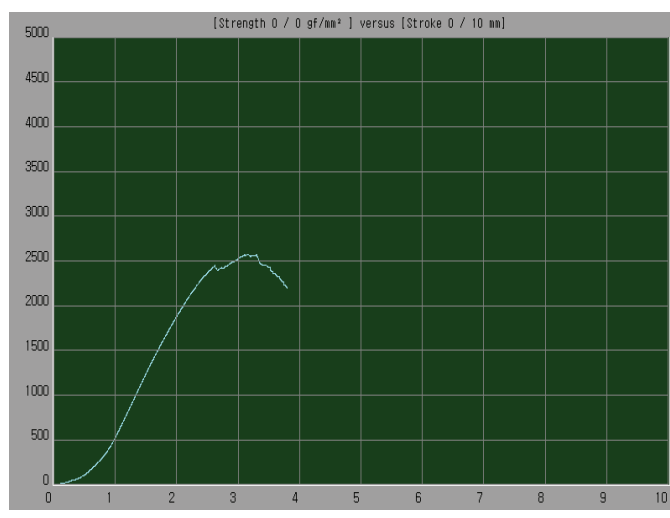

OSB

$\mathrm{X}$ axis: deflection(mm), $\mathrm{Y}$ axis: $\operatorname{load}(\mathrm{N})$

Fig. 3. Typical load-deflection curves of shear test in Plywood and OSB.

Table 2. Experimental results for structural panels subjected to five point banding test

\begin{tabular}{|c|c|c|c|c|c|}
\hline \multirow{2}{*}{\multicolumn{2}{|c|}{ Material }} & Plywood & E/OSB* & C/OSB* & N/OSB* \\
\hline & & \multicolumn{4}{|c|}{$\mathrm{N} / \mathrm{mm}^{2}$} \\
\hline \multirow{4}{*}{$\begin{array}{l}\text { Parallel to major } \\
\text { axis }\end{array}$} & Average & 1.71 & 1.32 & 1.93 & 1.67 \\
\hline & $\begin{array}{l}\text { Standard } \\
\text { deviation }\end{array}$ & 0.15 & 0.13 & 0.16 & 0.28 \\
\hline & Maximum & 1.90 & 1.54 & 2.17 & 2.24 \\
\hline & Minimum & 1.47 & 1.09 & 1.62 & 1.40 \\
\hline \multirow{4}{*}{$\begin{array}{l}\text { Perpendicular to } \\
\text { major axis }\end{array}$} & Average & 1.99 & 1.46 & 1.91 & 1.63 \\
\hline & $\begin{array}{l}\text { Standard } \\
\text { deviation }\end{array}$ & 0.32 & 0.28 & 0.26 & 0.28 \\
\hline & Maximum & 2.38 & 1.89 & 2.36 & 2.28 \\
\hline & Minimum & 1.25 & 0.95 & 1.35 & 1.10 \\
\hline
\end{tabular}

* E/OSB : Europe, C/OSB : Chile, N/OSB : North America (Canada)

of the middle layer of the OSB is discontinuous, which suggests that the splitting due to the load easily occurs.

The significant difference between rolling shear strength of the panels was first verified by ANOVA test and then Duncan's multiple test was conducted. The result shows that in terms of rolling shear strengthparallel to the longitudinal direction, Chilean OSB showed the highest shear performance and there was no statistically significant difference in shear performance between plywood and Canadian OSB as shown in Fig. 4.

The lowest shear performance was found in European OSBs, and statistically significant differences were also found when compared to the three other panels. The shear strength between panels perpendicular to the longitudinal direction is shown in Fig. 5, indicating that the plywood showed the highest shear performance, 

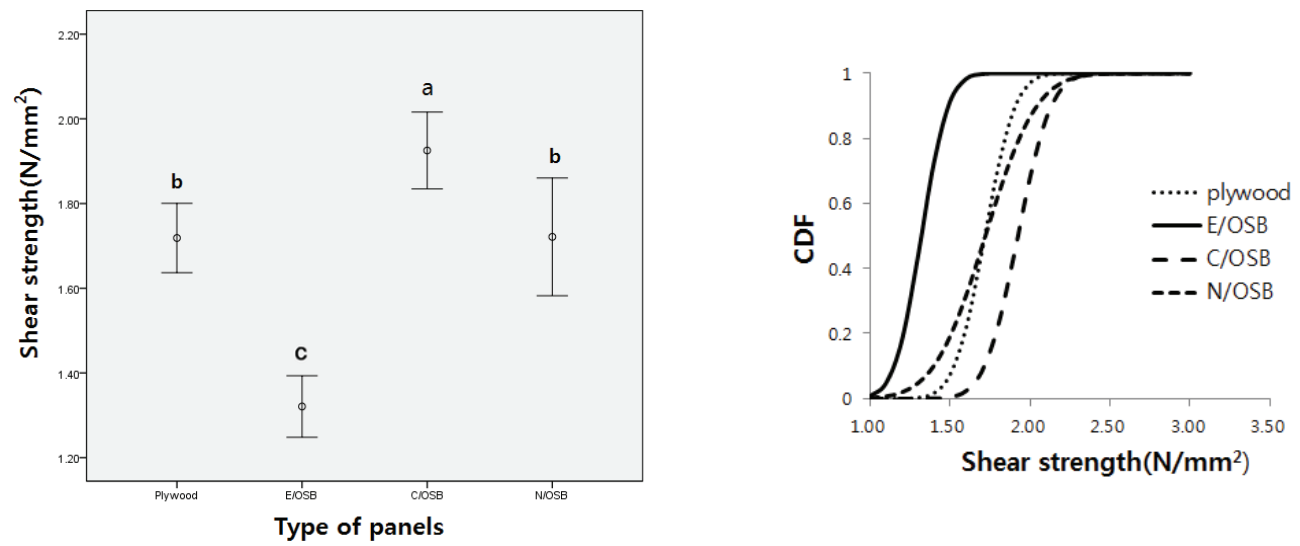

Groups with same letters in figure indicate statistical indifference between samples according to Duncan's multiply range test

Fig. 4. Statistics and cumulative probability distribution(CDF) of shear strength test parallel to major axis.
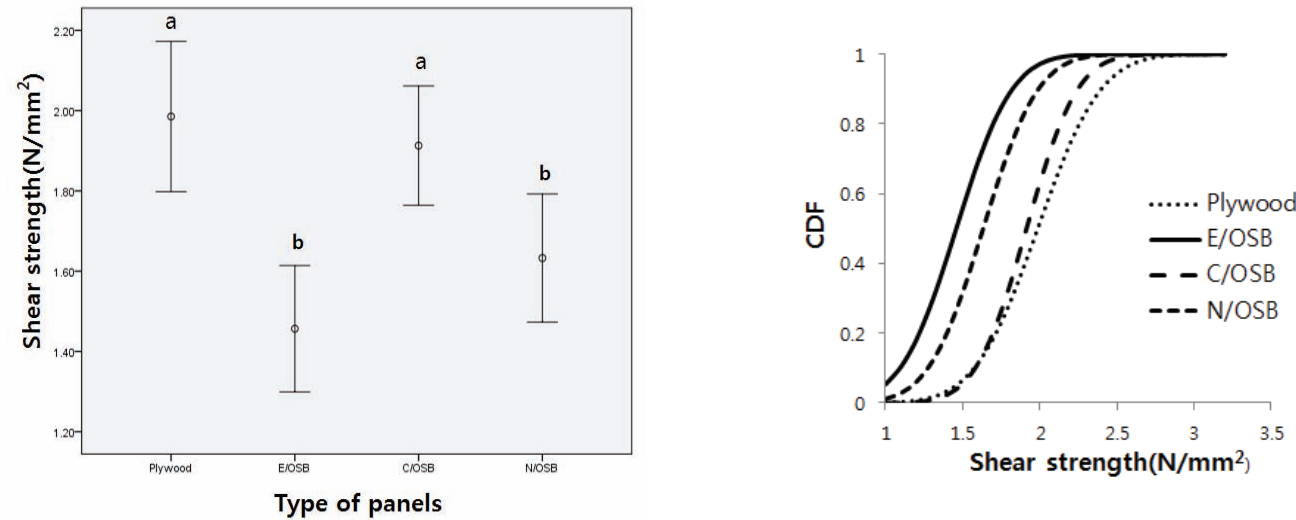

Groups with same letters in figure indicate statistical indifference between samples according to Duncan's multiply range test

Fig. 5. Statistics and cumulative probability distribution(CDF) of shear strength test in perpendicular to major axis.

with no statistically significant difference found when compared to the Chilean OSB.

Bradtmueller et al. (1997) reported that the rolling shear force was $0.89 \mathrm{~N} / \mathrm{mm}^{2}$ on average for the 23/32 inch OSB and that there was no significant difference according to the test direction, which was consistent with the result of this study.

Sretenovic et al. (2005) reported that shear performance of the plywood was higher than that of the OSB in the comparative study of the shear strength of plywood and OSB when 5 point load was applied. This is due to the density gradient in the OSB layer structure and the high ratio of middle layer with low density resulted in the weakened shear resistance capability.

The thickness of the their test specimens used was $20.5 \mathrm{~mm}$ for the plywood and $21 \mathrm{~mm}$ for the OSB. 
In the case of the OSB, the thickness of the middle layer with low density was $17 \mathrm{~mm}$, which resulted in the increase of the density gradient. The thickness of structural panel used in this study is $11 \mathrm{~mm}$ (plywood is $12 \mathrm{~mm}$ ), and the difference in the density between the surface and the middle layer is relatively small, so it is more influenced by the specific gravity.

No statistically significant difference was observed between the domestic plywood and the Canadian OSB, which was statistically verified to have the same shear performance when parallel to the longitudinal direction, and the Chilean OSB, which was statistically verified to have the same shear performance when perpendicular to the longitudinal direction. Therefore, it is considered that it is possible to yield the allowable stress of the same level as those of the two structural panels.

\subsection{Failure modes of structural panels}

Table 3 and 4 show the failure mode and the ratio of each structural panel. As shown in Table 3, failure modes by rolling shear were observed in C/OSB, $\mathrm{N} / \mathrm{OSB}$, and E/OSB, and the ratio was $100 \%$.

The Bradtmueller et al. (1997) showed that the rolling shear failure was $96-97 \%$ depending on the width of the test material regardless of the direction. The shear test by the 5-point bending test showed that most of the material failures were shear failure, and this study showed the same tendency.

In the case of plywood, the failure ratio by rolling shear was $47-53 \%$, followed by the combined bending failure and shear failure, and the delamination failure of the adhesive layer was $13 \%$. The shear failure of plywood and OSB both occurred between the points, and the failure due to the bending occurred at the center part of the specimen with vertical splitting.

The occurrence of failure between points is shown in Fig. 6. As shown in Fig. 6, the highest shear force is applied there in the shear force diagram showing the maximum shear force in this section.

Table 3. Type of failure mode of rolling shear test for each panel materials in parallel to major axis

\begin{tabular}{|c|c|c|c|c|}
\hline \multirow{2}{*}{ Type of failure } & \multicolumn{4}{|c|}{ Materials } \\
\hline & Plywood & $\mathrm{E} / \mathrm{OSB}$ & C/OSB & N/OSB \\
\hline Rolling shear & 7 & 15 & 15 & 15 \\
\hline Bending with shear & 6 & None & None & None \\
\hline Glueline failure & 2 & None & None & None \\
\hline No.of shear failure & $7 / 15$ & $15 / 15$ & $15 / 15$ & $15 / 15$ \\
\hline Shear failure (\%) & 47 & 100 & 100 & 100 \\
\hline
\end{tabular}

Table 4. Type of failure mode of rolling shear test for each panel materials in perpendicular to major axis

\begin{tabular}{lrrrr}
\hline \multirow{2}{*}{ Type of failure } & \multicolumn{3}{c}{ Materials } \\
\cline { 2 - 5 } & Plywood & E/OSB & C/OSB & N/OSB \\
\hline \hline Rolling shear & 8 & 15 & 15 & 15 \\
Bending with shear & 5 & None & None & None \\
Glueline failure & 2 & None & None & None \\
No.of shear failure & $8 / 15$ & $15 / 15$ & $15 / 15$ & $15 / 15$ \\
Shear failure (\%) & 53 & 100 & 100 & 100 \\
\hline
\end{tabular}




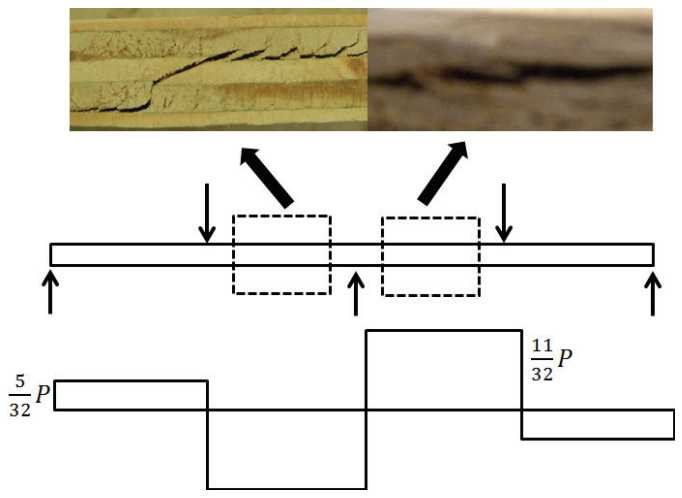

Fig. 6. Shear failure of OSB and plywood at the maximum shear stress region with shear force diagram.
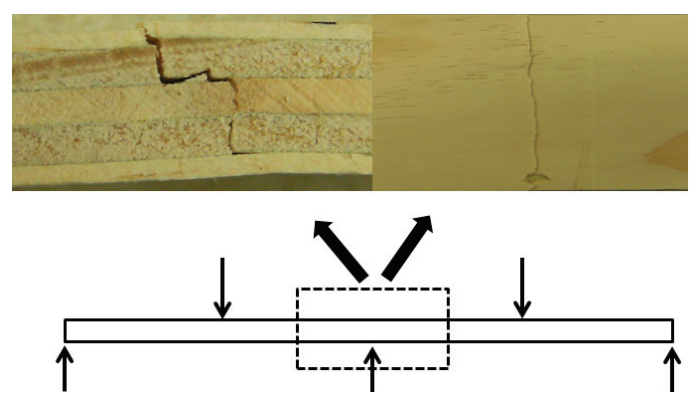

Fig. 7. Bending failure of plywood at the maximum moment stress region.

Since the shear strength of OSB depends on the weakest layer of middle layer with low density due to density gradient, it is thought that if shear stress exceeding the shear strength of middle layer is generated, delamination of adhesive layer occurs, and failure occurs at this part.

In the case of plywood with bending failure, as shown in Fig. 7, since the maximum bending moment occurs at the center, it is thought that failure occurs when the bending performance of the plywood is exceeded at this position.

\section{CONCLUSION}

The 5-point bending test method of ASTM D 2718 was used to determine the rolling shear force of imported OSBs and domestic plywood, which are currently used as typical cover materials in wood construction, and the results are analyzed.

The findings show that when parallel to the main axis, the highest shear force was $1.19 \mathrm{~N} / \mathrm{mm}^{2}$ for Chilean OSB, and $1.67 \mathrm{~N} / \mathrm{mm}^{2}$ for Canadian OSB, 1.71 $\mathrm{N} / \mathrm{mm}^{2}$ for plywood, and $1.32 \mathrm{~N} / \mathrm{mm}^{2}$ for European OSB which is the lowest value, respectively. No statistically significant difference was found.

In the case of perpendicular direction to the main axis, the shear force was $1.91 \mathrm{~N} / \mathrm{mm}^{2}$ for Chilean OSB and $1.99 \mathrm{~N} / \mathrm{mm}^{2}$ for plywood, representing the highest shear forces, and $1.63 \mathrm{~N} / \mathrm{mm}^{2}$ for Canadian OSB and $1.46 \mathrm{~N} / \mathrm{mm}^{2}$ for European OSB, with no statistically significant difference found. There was little difference between the both directions in each panel.

In the three kinds of imported OSB, all the failures were by shear, and in the case of plywood, shear, delamination of the adhesive layer, failure due to bending and shear, and so on were observed, indicating it is affected by its layer structure.

From these results, it is concluded that domestic plywood can be used for wood construction material compared with imported OSBs, but it is necessary to suggest reasonable design standards through additional performance verification as a structural panel material.

\section{ACKNOWLEDGMENT}

This research was supported by the Daegu University Research Grant 2015.

\section{REFERENCES}

American Society for Testing and Materials. 2000. 
Standard Test Methods for Structural Panels in Planar Shear (Rolling Shear). ASTM D 2718. ASTM, West Conshohocken, Pa.

Bradtmueller, J.P., Hunt, M.O., Fridley, K.J., Mccabe. G.P. 1997. Mechanical properties of OSB via the five-point bending test. Forest Products Journal 47(9): 70-77.

Frank, L., Bruce, A.C. 2000. Shear strength in structural composite lumber. Journal of Materials in Civil Engineering 12(3): 196-204.

Fridley, F., French, L. 2000. Five-point bending test for determination of edgewise shear in strructural panels. Forest Products Journal 50(5): 43-46.

Kim, W.C., Dharan, C.K.H. 1995. Analysis of five-point bending for determination of the interlaminar shear strength of unidirectional composite materials. Composite Structures. 30(3): 241-251.

Ministry of Land, Infrastructure, and Transport. 2017. MOLIT Statistics system - Statistics of housing construction (construction consent) - Housing construction records.

Nadir, A., Jerrold, E.W. 2007. Effects of various fireretardants on plate shear and five-point bending shear properties of plywood. Forest Products Journal 57(4): 44-49.
Oh, S.C. 2013. Withdrawal and Lateral Resistance of Nail Joints Composed of Dimension Lumber and OSB in Light-Frame Wood Construction. Journal of the Korean Wood Science and Technology 41(3): 211-220.

Oh, S.C. 2013. Determining Shear Modulus of 3-ply Laminated Veneer Lumber by Uniaxial Tension Test. Journal of the Korean Wood Science and Technology 41(5): 425-431.

Shrestha, D. 1999. Shear properties tests of oriented strandboard panels. Forest Products Journal 49(10): 41-46.

Sretenovic, A., Gindl, W., Müller, U. 2005. Comparison of the in-plane shear strength of OSB and plywood using five point bending and EN 789 steel plate test methods. Holz als Roh-und Werkstoff 63(2): 160-164.

Thomas, W.H. 2004. Planar shear moduli of rigidity of an oriented strand board from bending and shear tests. Materials and Structures 37(7): 480-484.

Hwang, K.H., Park, M.J. 2008. Nail Shear Performance of Structural Members With OSB. Journal of the Korean Wood Science and Technology 36(4): 66-76. 


\title{
APPENDIX
}

\author{
(Korean Version)
}

\section{5 점 휨하중 시험법을 사용한 구조용 판넬의 굴림전단강도}

요약 : 본 연구는 ASTM D2718의 5점 휨하중 시험법을 사용하여 OSB(oriented strand board)와 국산합판의 굴림전단성능을 평가하기 위하여 수행되었다. 각 시험용 판넬에 대해 길이방향에 평행한 것과 수직인 시험편을 제작하여 각각 시험하였으며, 파괴양상을 관찰하였다. 시험 결과 굴림전단력은 강축방향에 평행한 경우 $1.32-1.938 \mathrm{~N} / \mathrm{mm}^{2}$, 강축방향에 수직인 경우 1.46 $-1.99 \mathrm{~N} / \mathrm{mm}^{2}$ 정도로 나타났으며 방향에 따른 차이는 크게 나타나지 않았다. 국산합판은 길이방향에 평행한 경우는 캐나다산 $\mathrm{OSB}$ 와, 수직인 경우는 칠레산 OSB와 통계적으로 차이가 나타나지 않았다. 파괴는 OSB에서는 모두 전단에 의한 파괴가 나타났으며, 합판의 경우에는 전단, 접착층의 박리, 휨과 전단에 의한 복합파괴가 관찰되었다.

\section{1. 서 론}

현재 국내의 목조건축 시장은 연간 15,000채 전후로 주택이 시공될 정도로 확대추세에 있으며 2017년 현재 국토교통부의 건축허가 및 착공통계에서 보면 목조 13938건, 조적조 주택 7494건으로 나타나 조적조 주택의 허가 및 착공건수를 두 배정도 능가하는 경향을 보여주고 있다( MOLIT - Statistics of housing construction-Housing construction records. 2017). 목조건축에 사용되는 주재료는 규격재(dimension lumber)와 구조용 판넬(structural panel) 등 공학목재가 대부분이며 공학목재는 모두 성능이 인증된 제품이어야 목조구조물에 사용이 가능하다. 공학목재 중 구조용 판넬로 사용되는 것은 주로 OSB(oriented strand board)와 구조용 합판으로 이들 재료는 합리적인 가격과 적합한 구조성능으로 지붕, 바닥 및 벽체 구조의 덮개재로 주로 사용된 다. OSB는 적층복합재료로 목재처럼 직교이방성재료로 간주되므로 층간 전단(interlaminar shear)과 두께를 통한 전단(shear through the thickness) 성능을 가지게 된다. 층간전단은 판넬의 면을 따라 외력이 가해지면서 생기는 전단으로 인해 굴림전단 (rolling shear) 또는 면전단(planar shear)이라고도 한다(Shrestha, 1999). 목조주택의 구조 특성 상 이들 덮개재는 장선위에 놓여 져서 수직하중 저항구조로서 또 수평격판구조를 통해 수평하중 저항 구성요소로서의 역할을 담당하며, 벽체 구조에서는 수평하중 저항요소의 주요 부재로서의 사용되므로 적절한 구조성능을 견지하고 있어야 한다. OSB의 전단성능은 국내에 경우 OSB 자체가 아니라 주로 OSB와 못 접합부간의 전단 시험이 주로 수행되었으며 (Hwang and Park, 2008; Oh, 2013) 단판적층재 (LVL)에 관한 전단강성을 인장시험을 통해 측정한 연구가 수행되었다(Oh, 2013). 이러한 구조용 판넬 자체의 전단성능은 전단성능 시험법 자체의 어려움과 시험에 필요한 비용이 너무 커서 이로 인해 품질관리적인 측면에서 생략되는 경우가 많았다 (Fridley and French, 2000). 하지만 목조건축에서 OSB의 사용이 보편화 되면서 전단성능은 바람과 지진 등 측방하중에 따른 구조성능의 주요 인자로 자리매김하고 있다.구조용 덮개로 사용되는 판넬은 측방하중으로 인해 전단에 노출되기 때문에 이에 대한 고려가 반드시 필요하다(Nadir and Jerrold, 2007). 구조용 판넬의 직접적인 전단성능 시험법은 ASTM D2718이 있다. 이 시험법에서 5점 휨하중 시험법은 시험 방법이 간단하고 경제적이며 전단성능을 직접 측정이 가능하기 때문에 5점 휨하중에 의한 시험방법이 많이 사용되고 있다(Thomas, 2004; Nadir and Jerrold, 2007). Sretenovic, A. et al.(2005)은 5점 휨하중 시험법과 EN 789 시험법을 적용한 합판과 OSB의 굴림전단 성능비교 연구를 수행한 바 있으며 5점 휨하중 시험법은 구조용 판넬 뿐만 아니라 LVL(laminated veneer lumber), PSL(parallel strand lumber)과 같은 구조용 복합재에도 적용되었다 (Bradtmueller et al., 1998; Frank and Bruce, 2000; Fridley and French, 2000). 특히 복합재에 대한 5점 휨하중 시험법은 시험편 전체에 걸쳐 전단응력의 영향이 매우 크고 휨 응력이 제로에 가까운 장점을 가지고 있어서 방향성을 갖는 복합재의 층간전단력을 측정하는데 매우 효율적인 방법이라고 하였다(Kim and Dharan, 1995). 본 연구에서는 목조건축 현장에서 많이 사용되고 있는 OSB와 국산 합판을 대상으로 5점 휨하중 시험법을 적용하여 이들에 대한 굴림 전단력을 측정하고 그들 간의 성능을 비교·검토해 보고자 하였다.

\section{2. 재료 및 방법}

\section{1. 시험재료}

본 연구에서 사용된 구조용 판넬은 4 종류로 국내산 합판과 수입 OSB 3종으로 각각 유럽과 캐나다, 칠레로부터 수입된 것으로 
전문업체로부터 구입하여 시험재료로 사용하였다. $4 \times 8$ 크기의 각 구조용 판넬의 두께, 밀도 및 함수율은 Table 1 과 같다.

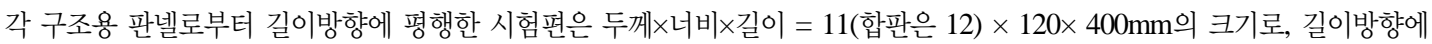
수직인 시험편은 두께 $\times$ 너비 $\times$ 길이 $=11$ (합판은 12$) \times 120 \times 290 \mathrm{~mm}$ 의 크기로 한 판넬에서 5 개씩 시험편을 제작하여 종류별로 15 개의 시험편을 각각 제작하였다. 제작된 시험편은 온도 $20^{\circ}$ C. 상대습도 $65 \%$ 의 조건에서 약 열흘간 조습처리 한 다음 시험에 사용하였다.

\section{2 실험방법}

준비된 각 시험편에 대하여 만능강도시험기(DTU 900-H)를 사용하여 ASTM D 2718의 규정에 따라 Fig. 2와 같이 시험편을 설치하고 하중을 가하여 파괴 시 최대 하중을 측정하였다. 경간(L)은 ASTM의 규정에 따라 판넬의 길이방향에 평행한 시험편은 경간의 최소치인 두께의 16 배에 해당하는 $180 \mathrm{~mm}$ 로 하였으며, 길이방향에 수직인 시험편은 경간의 최소치인 두께의 11 배에 해당하는 $120 \mathrm{~mm}$ 로 하였다. 시험 시 하중속도는 $1.3 \mathrm{~mm} / \mathrm{min}$ 를 적용하였으며 측정된 최대 하중값을 사용하여 구조용 판넬의 굴림전단강도(fv)를 식 (1)에 따라 산출하였다.

각 측정된 값에 대하여 통계적 차이의 유무를 검증하기 위해 SPSS 통계프로그램을 사용하여 ANOVA 검정과 Duncan의 다중검정 분석을 실시하였다.

\section{3. 결과 및 고찰}

\section{1 구조용 판넬의 굴림전단성능}

5점 휨하중에 의한 휨시험에서 전형적인 하중-변형 곡선은 Fig. 3과 같다. 합판의 경우 접착층 분리에 의한 경우를 제외하고는 그림에서 보는 것처럼 일차 파괴가 진행된 이후에도 지속적으로 전단에 저항하는 경향을 나타내었으며 OSB의 경우에는 모두 굴림전단에 의한 파괴로 인해 최대하중 도달 후 급속히 저하되는 현상을 보였다.

Table 2는 각 구조용 판넬에 대한 길이방향에 평행/수직한 굴림전단강도와 최대 휨 응력을 나타낸 것이다. Table 2에서 보듯이 길이방향에 평행한 굴림전단강도는 C/OSB, 합판, N/OSB, $\mathrm{E} / \mathrm{OSB}$ 순으로 나타났으며, C/OSB의 경우 최대 굴림전단강도 값은 $1.90 \mathrm{~N} / \mathrm{mm}^{2}$ 로 가장 높은 값을 보여주었다. Bradtmuller et al.(1997)은 5점 휨 시험에서 시험편의 폭과 경간을 달리한 $\mathrm{OSB}$ 의 평균 굴림전단강도는 $0.81 \mathrm{~N} / \mathrm{mm}^{2}$ 이라고 보고한 바 있으며, Shrestha(1998)는 $1.16 \mathrm{~N} / \mathrm{mm}^{2}$, Fridley와 French(2000)은 $1.13 \mathrm{~N} / \mathrm{mm}^{2}$ 이라고 한 연구 결과와 비교해 볼 때 유럽산 OSB를 제외하고는 모두 높은 값을 보여주었다. 이는 시험체의 두께와 폭 같은 크기 및 경간 조건, 방향들에 따른 영향으로 생각된다.

길이방향에 수직한 굴림전단강도는 합판, C/OSB, N/OSB, E/OSB 순으로 나타났으며, 합판의 경우 최대 굴림전단강도 값은 $2.38 \mathrm{~N} / \mathrm{mm}^{2}$ 로 가장 높은 값을 보여주었다. 이는 길이방향에 평행한 굴림전단강도의 경우와는 다른 경향으로 Sretenovic et al.(2004)이 지적한 바와 같이 OSB의 중층의 구조가 불연속적이므로 시험하중에 의한 할렬이 쉽게 발생하는 특성에 따른 것으로 생각된다.

각 판넬간의 산출된 굴림전단력간의 차이는 통계분석을 통해 구조용 판넬 간의 유의차를 먼저 ANOVA 테스트를 통해 검정한 후 Duncan의 다중검증으로 검정하여 이들 간의 차이를 분석한 결과 길이방향에 평행한 판넬 간의 굴림전단력은 Fig. 4 와 같이 칠레산 OSB가 가장 높은 전단성능을 나타내었으며 합판과 캐나다산 OSB의 전단성능에는 통계적으로 유의한 차이가 나타나지 않았다. 가장 낮은 전단성능은 유럽산 OSB에서 나타났으며, 다른 세 종류의 판넬과도 통계적으로 유의한 차이가 있는 것으로 나타났다. 길이방향에 수직한 판넬 간의 굴림전단력은 Fig. 5 와 같이 합판이 가장 높은 전단성능을 나타내었으며 칠레산 OSB와는 통계적으로 유의차가 인정되지 않았다. 캐나다산 OSB와는 유의차가 인정되었으며 가장 낮은 전단성능을 보인 유럽산 OSB는 캐나다산 OSB와 통계적으로 유의한 차이는 인정되지 않았다.

Bradtmueller et al.(1997)은 23/32인치 OSB에 대한 연구에서 굴림전단력은 평균 $0.89 \mathrm{~N} / \mathrm{mm}^{2}$ 으로 나타난다고 한 바 있으며 시험 방향에 따라 큰 차이는 나타나지 않는다고 한 바 본 연구결과에서도 같은 경향을 보였다. Sretenovic et al.(2005)은 5점 하중에 따른 합판과 OSB의 전단강도 비교시험에서 합판은 OSB보다 높은 전단성능을 보여 주었으며 이는 OSB의 층 구조에서 밀도경사로 인한 것이며 낮은 밀도를 갖는 중층의 비율이 높음에 따라 전단저항능력이 약화된 것이라고 하였다. 이 결과는 사용된 시험편의 두께가 합판은 $20.5 \mathrm{~mm}, \mathrm{OSB}$ 는 $21 \mathrm{~mm}$ 였으며 OSB의 경우 밀도가 낮은 중층의 두께가 $17 \mathrm{~mm}$ 에 달해 이로 인해 밀도경사가 커져 생긴 결과로 생각되며 본 연구에서 사용된 구조용 판넬의 두께는 $11 \mathrm{~mm}$ (합판은 $12 \mathrm{~mm}$ )로 표면과 중층의 밀도의 차이는 상대적으로 작게 되어 비중에 따란 영향이 더 크게 나타난 것으로 판단된다. 국산 합판은 길이방향에 평행한 경우 동일한 전단성능을 갖는 것으로 통계적으로 검증된 캐나다산 OSB와 길이방향에 수직한 경우 동일한 전단성능을 갖는 
것으로 통계적으로 검증된 칠레산 OSB와 통계적으로 유의차가 인정되지 않았으므로 두 구조용 판넬과 비교할 때 상대적으로 동일한 수준의 허용응력의 산출이 가능하리라고 생각된다.

\section{2 구조용 판넬의 파괴형상}

Table 3과 4는 각 구조용 판넬에 대한 파괴 양상과 그 비율을 나타낸 것이다. Table 3에서 보듯이 C/OSB, N/OSB, E/OSB 에서는 모두 전단에 의한 파괴양상이 나타났으며, 그 비율은 $100 \%$ 였다. 앞서 언급한 Bradtmueller et al.(1997)의 연구에서 전단파괴는 방향에 상관없이 시험재의 폭에 따라 96-97\% 정도로 나타남을 보여주어 5점 휨하중 시험법에 의한 전단시험은 재료의 파괴가 전단파괴가 대부분이므로 효율적인 시험법임을 입증한 바 있으며 본 연구에서도 같은 경향을 보여주었다. 합판의 경우 전단에 의한 파괴비율은 47-53\% 정도로 나타났으며 휨과 전단이 복합된 파괴가 그 다음 순으로 나타났으며 접착층의 파괴는 $13 \%$ 로 각각 나타났다. 합판과 OSB의 전단파괴는 지점과 지점사이에서 모두 발생하였으며, 휨에 의한 파괴는 시험편의 중앙부에서 발생하여 수직으로 할렬이 생기면서 파괴가 진전되는 양상을 보여주었다. 지점사이에서 파괴되는 것은 Fig. 6에서 보듯이 전단력선도 상에서 가장 높은 전단력이 작용하는 구간으로 이 구간에서 굴림 전단력이 최대값을 보여주기 때문으로 생각된다.

한편 합판에서 접착층의 박리의 발생위치는 전단파괴와 같이 지점사이에서 발생하였으며 이 역시 최대 전단력에 의한 영향으 로 생각된다. OSB의 전단강도는 밀도경사로 인해 낮은 밀도를 가지는 중층의 가장 약한 층에 의해 좌우되므로 중층의 전단강도 를 초과하는 전단응력이 발생하면 이 부분에서 접착층의 박리가 일어나고 파괴에 이르게 되는 것으로 생각된다. 휨 파괴가 일어나는 합판의 경우는 Fig. 7에서 보듯이 최대 휨모멘트가 중앙에서 작용하고 있으므로 이 위치에서 합판의 휨 성능을 초과하 면 파괴가 발생하는 것으로 생각된다.

\section{4. 결 론}

현재 목조건축에서 대표적인 덮개재로 많이 사용되고 있는 수입산 OSB와 국산 합판의 굴림 전단력을 측정하기 위해 ASTM D 2718의 5점 휨하중 시험법을 적용하고 그 결과를 분석하였다. 시험결과 주축 방향에 대해 평행한 경우 칠레산 OSB $1.93 \mathrm{~N} / \mathrm{mm}^{2}$ 로 가장 높은 전단력을 나타내었으며 캐나다산 $\mathrm{OSB}$ 는 $1.67 \mathrm{~N} / \mathrm{mm}^{2}$, 합판은 $1.71 \mathrm{~N} / \mathrm{mm}^{2}$ 로 나타나 통계적으로 차이가 없었으며 유럽산 OSB가 $1.32 \mathrm{~N} / \mathrm{mm}^{2}$ 로 가장 낮은 값을 나타내었다. 주축방향에 대해 수직인 경우 칠레산 OSB $1.91 \mathrm{~N} / \mathrm{mm}^{2}$, 합판은 $1.99 \mathrm{~N} / \mathrm{mm}^{2}$ 로 가장 높은 전단력을 나타내었으며 캐나다산 OSB $1.63 \mathrm{~N} / \mathrm{mm}^{2}$, 유럽산 OSB $1.46 \mathrm{~N} / \mathrm{mm}^{2}$ 로 통계적으로 차이가 없었다. 각 판넬에서 양 방향 간의 차이는 거의 나타나지 않았다. 세 종류의 수입산 OSB에서 파괴는 모두 전단에 의한 파괴가 나타났으며 합판의 경우에는 전단, 접착층의 박리, 휨과 전단에 의한 파괴 등 다양하게 나타났으며, 이는 합판의 층 구조에 따른 영향으로 분석되었다.

이들 결과로부터 수입산 OSB와 비교하여 목조건축에 국산합판의 사용이 가능하다고 보여지지만 국산합판의 구조용 판넬재 로서의 추가적인 성능 인증을 통하여 합리적인 설계 기준값을 제시할 필요성이 있어야 할 것으로 생각된다. 